vision remains, the public will not purchase sets. Even if only one provincial station were started, it would show that television has been accepted and would give a tremendous stimulus to the industry. The United States has studied the possibilities of television and by next September there will be twenty stations in operation. If good progress had been made in Great Britain in providing provincial stations and services, manufacturers in this country could have produced sets in such quantities that the initiative could have been taken in the South American countries, in South Africa and in other places. Unless the rate at which we are now moving is accelerated, the stations to be provided in these places will be American stations, and if this were so, the sets now being produced in Great Britain would not work when connected to them.

\section{Changes in Bird Population}

Is a civilized country, where social changes are rapid and often extensive, the wild population, whether of birds or other creatures, is undergoing constant readjustment. Much of the change passes unnoticed, and much, even if it be observed by local residents interested in natural history, goes unrecorded. The Royal Society for the Protection of Birds is doing good work in stimulating interest in the changing phases of bird population by offering the Medal of the Society and money prizes for the best paper on "Changes in the bird population of Britain during the present century, in a district or districts known to the writer, in regard to the increase or decrease of species named, what cause or causes can be assigned, and what (if any) effect has been observed". The causes which suggest themselves to the Society include-the universal use of the motorcar and the popularity of 'rambling', opening up hitherto secluded places ; afforestation ; road development ; the disappearance of hedges ; the invasion of the open country by factories; the replacement of open ditches by underground drains. There is also deliberate encouragement of birds to be reckoned with, by the creation of bird sanctuaries, the influence of the law's protection, and the altered outlook of the people towards the amenity of bird life generally. The competition should prove to be interesting and useful, although it is obvious that great care will have to be taken in sifting and adjudicating upon the causes alleged to be responsible for any change. The competition is referred to in the spring number (1939) of Bird Notes and News.

\section{The National Physical Laboratory}

THE report of the Laboratory for the year 1938 is a royal octavo pamphlet of 147 pages published by H.M. Stationery Office at 2s. 6d. The general report of the Executive Committee occupies 14 pages and is followed by reports of the superintendents of the separate Departments of Physics, Electricity, Radio, Metrology, Engineering, Metallurgy, Aerodynamics and Ship Propulsion, which enter into more detail, extending to 114 pages, and each concludes with a list of papers published by the Department during the year. They seem remarkably free from obscure technical expressions and can in consequence be read with ease by the general public. The changes of staff have been more important than usual. Three directors have been in charge during the year and one superintendent has become director of research in another Government department, while industry and Government departments have absorbed other members of the staff. Lectures on the work of the Laboratory have again been given in large industrial centres (17), and as usual a large number of requests for scientific information on points arising in industrial work have been answered by the Laboratory without charge.

\section{Utilizing Sunshine}

Dr. C. G. Aввот, the secretary of the Smithsonian Institution, has published a description of recent devices he has used in converting sunshine into power (Smithsonian Misc. Coll., 98, No. 5; March 30, 1939). In general, the sun's rays are focused by a cylindrical mirror on to an axial glass tube through which, for the distillation of water or the generation of steam, water flows, and for cooking purposes a black liquid of boiling point above $350^{\circ} \mathrm{C}$. The mirror is now made of flexible sheet known as 'Aloa' and the axial tube is surrounded by a concentric vacuum tube. While coal is cheap, Dr. Abbot does not expect extensive use of such devices, but under favourable conditions small units up to five horse-power with an efficiency of conversion of solar to mechanical energy of the order of 15 per cent and a cost of a farthing per horse-power hour may be possible. At present the initial cost of the apparatus is high, but when thousands are required prices will fall.

\section{Books on International Relations}

A "ShorT List of Books on International Rela. tions" recommended by the Education Committee of the League of Nations Union (15, Grosvenor Crescent, S.W.1) includes 141 titles arranged in two lists, the first consisting of books for boys and girls and the second of books for students and teachers. The latter is arranged in six sections dealing with the League of Nations, with education, with international relations, with special problems, with collective security and peaceful change and with colonies and raw materials, respectively. The majority of the books are of the descriptive type, but a number of constructive critical works are included, mostly from rather a Left Wing point of view. In addition, the list gives the titles of a number of songs and celebrations as well as of maps and periodicals, and forms on the whole a useful introduction to the study of international relations.

\section{A Mosquito Invasion of South America}

THE possibility of the introduction of a disease into a country at present free from it by air-transport of the infected insect-vector has long been recognized, for example, yellow fever by its infected mosquitocarrier. That this menace is real and not hypothetical 
is demonstrated by the fact that an African species of malaria-carrying mosquito, Anopheles gambice, has become established in South America. According to Science Service, this mosquito has been found at Natal, Brazil, and in localities two hundred miles west and north of Natal, and has already caused severe outbreaks of malaria. This mosquito was probably introduced as a stowaway on one of the aeroplanes of the French airline between Dakar in West Africa and Natal in Brazil.

\section{Cadmium Pigments}

WE have received from Messrs. Johnson and Matthey, Hatton Garden, London, E.C.1, a copy of a booklet on cadmium pigments. These have cadmium sulphide as a basis, and the sulphide itself can be obtained in any colour from pale yellow to orange. Redder shades are obtained by the incorporation of selenium, so that it is possible to get a complete range from pale yellow, through orange and red, to deep maroon. Cadmium lithopones are also available. The properties of the pigments are described.

\section{High Vacuum Distillation}

ThE Transactions of the Society of Chemical Industry (58, No. 2 ; 1939) contain several papers presented last November to a meeting of the Chemical Engineering Group which dealt with the industrial applications of high-vacuum distillation. Pressures of the order of $10^{-6} \mathrm{~mm}$. are concerned and the technical apparatus is described with drawings. One important application of the technique is to the concentration of vitamins from oils.

\section{Earthquake in Solomon Islands of April 30, 1939}

FURTher news has come to hand concerning this shock. According to the Bureau central seismologique de Strasbourg, from reports received from thirty seismological stations the epicentre of the most severe shock was at $7 \cdot 5^{\circ} \mathrm{S}$., $159 \cdot 6^{\circ} \mathrm{E}$., depth of focus probably $100 \mathrm{~km}$. and starting time $2 \mathrm{~h}$. $55 \mathrm{~m}$. $35 \mathrm{~s}$. G.C.T. According to reports from the islands, the shock and after-shocks lasted for several days. One of the islands most seriously affected was Guadalcanar, where a number of buildings were wrecked, and where a wave following the shock swamped a number of native villages. On Ysabel Island houses were damaged, and in the Cape Marsh district of the Russell Islands wharves and houses were wrecked. In the island of Savo, surface faults were visible, but there was no loss of life. Altogether nine children and three adults of the indigenous population were drowned.

\section{Earthquake near Japan}

UsING reports from the seismological stations at Honolulu, Victoria, Tucson, Manila, Huancayo, Zikawei, Burlington and Philadelphia, the United States Coast and Geodetic Survey has made a preliminary determination of the epicentre and initial time as follows : lat. $37^{\circ} \mathrm{N}$., long. $142^{\circ} \mathrm{E}$., November 30,2 h. 29 m. 52 s. G.C.T. The epicentre is under the ocean bed to the north-east of the coast of the main island of Japan, and is the same as that for the earthquake of November 22, lh. 14.1m. G.C.T. No effects of this shock have been reported from land.

\section{Commonwealth Fund Fellowships Awards}

THE Committee of Award of the Commonwealth Fund fellowships has made the following appointments, among others, to fellowships tenable by British graduates in American universities for the two years beginning September 1939: C. A. U. Craven, Imperial College of Science and Technology, University of London, to Harvard University, in geology ; Dr. B. M. Crowther, Clare College, Cambridge, to the Massachusetts Institute of Technology, in physics; G. M. Henderson, University of Edinburgh, to Princeton University, in chemistry; P. B. Hunt, Christ Church, Oxford, to Columbia University, in economics ; G. O. Jones, Emmanuel College, Cambridge, to the Massachusetts Institute of Technology, in engineering; J. P. Keane, University of Wales and University of London, to the University of Michigan, in economics ; Edward Lee, University of Manchester, and University of Cambridge, to the University of Michigan, in physics ; Nicholas Miller, Imperial College of Science and Technology, University of London, to the University of California, in engineering; D. G. Northcott, St. John's College, Cambridge, to Princeton University, in mathematics; G. W. Parnell, University of Bristol, to the University of California, in zoology ; J. H. Read, University of St. Andrews, and Emmanuel College, Cambridge, to Columbia University and the American Film Center, New York, in cinematography; J. A. Scott, Trinity College, Oxford, to the University of Pennsylvania, in economics; Dr. E. V. Watson, University of Edinburgh, to Harvard University, in botany ; E. R. Winton, University of St. Andrews, to the Massachusetts Institute of Technology, in engineering; N. A. Wylie, Oriel College, Oxford, to Yale University, in forestry.

THE following have been appointed to fellowships tenable by candidates from the British Dominions : H. C. Corben, University of Melbourne, and Trinity College, Cambridge, to the University of California, in physics; Dr. A. P. Guinand, University of Adelaide, New College, Oxford, to Princeton University, in mathematics. The following have been appointed to fellowships tenable by candidates holding appointments in Government service overseas : H. L. Hume, University of New Zealand, of the Public Works Department, Government of New Zealand, to the University of California, in engineering ; M. R. Jacobs, University of Adelaide, and St. Catherine's Society, Oxford, of the Department of the Interior, Government of Australia, to Yale University, in forestry ; C. S. Kelly, Balliol College, Oxford, of the Indian Civil Service, Government of Burma, to Yale University, in anthropology ; S. L. Macindoe, University of Sydney, of the Department of Agriculture, Government of New South Wales, to the University of Minnesota, in agriculture. The following have been appointed to fellowships tenable 